\title{
TOURISM IN THE MORAVIAN KARST
}

\author{
Jiří Vaníček \\ Prague University of Economics and Business, Faculty of International Relations, \\ Department of Tourism, \\ W. Churchill sq 1938/4., 13067 Prague 3 - Žižkov, Czech Republic \\ e-mail: jiri.vanicek@vse.cz
}

\begin{abstract}
The article focuses on sustainable tourism in the protected landscape area of the Moravian Karst. Participants in the research included municipalities, stakeholders in the field of tourism, residents, and visitors. The Moravian Karst (CHKO) is an example of a preserved landscape area that managed to combine environmental protection and tourism. Visits to caves prevail; however, visitors do not limit their activities to this type of tourist attraction. They also visit other natural as well as cultural sights. Most municipalities think that the existence of the Moravian Karst CHKO positively influences the development of tourism. They appreciate new jobs and the inflow of finance from the regional budget.
\end{abstract}

\section{Keywords}

Protected landscape area; Sustainable tourism; Moravian Karst; Visitor; Resident.

\section{Introduction}

The international community recognized the urgency of environmental protection at the UN Conference on the Environment in Stockholm in 1972. Participants at the conference pointed out that the Earth is endangered by people themselves. The conference significantly influenced the formation of the worldwide environmental protection policy. [4]

In 1983 the World Committee for the Environment and Development was established. The committee was the first one to offer a definition of sustainable development in a paper called "Our Shared Future" in 1987. Sustainable development is defined as follows: "Sustainable development is such that fulfils the needs of the present generation without endangering the ability of future generations to fulfil their needs"

One of the key factors for the tourism industry to succeed in all areas, including rural and protected areas, is the support of a local community [2], [3]. Changes in residents' attitudes are important since they provided a way that planners and tourism practitioners should follow in order to achieve an adequate level of community tourism development and planning. This adequate level was connected with satisfied quality of life, increased opportunities for new jobs, reduced costs of living [5]. A few studies underlined that residents' sense of well-being and their sustenance for tourism development were connected with how the outcomes of tourism were evaluated by the members of a community [1]. This means that if residents perceive a positive benefit-cost ratio, it is more likely that they will support tourism and take active roles in tourism activities [8]. Economic benefits from tourism, like employment and economic gain, were used as indicators to examine community attachment, residents' quality of and satisfaction with life, and attitudes towards tourism. Although economic benefits were a significant predictor, a combination of factors, such as social, emotional, and economic, performed better in analyzing how residents' perceived values influence the quality of life, their satisfaction with life, and support for further tourism development [7], [12]. According 
to Sweenev and Soutar [9], important aspects of tourism development were also those intangible values that can be derived from place attachment or personal benefits. Since communities may have different traditions, cultures and natural resources, residents' level of support and attitudes towards tourism development and perceived quality of life may depend on the nature of a destination. The term 'sustainable development' has been used since the 1960s.

The industrialization era which started in Czechoslovakia after WWII influenced the environment significantly. A formerly rural country became an industrial one. This change resulted in a significant increase in pollution due to the construction of power plants, chemical factories and raw material mines. After the Velvet Revolution in 1989, the Ministry of the Environment and the Czech Environmental Inspection were established. Soon after that, the parliament passed significant laws to protect various aspects of the environment. [13]

To maintain sustainability, it is crucial to harmonize economic interests and environmental needs and to balance technological progress and environmental limits. It means that sustainable development rests on three basic pillars: the economic, the social and the environmental ones. [6]

Tourism in protected landscape areas is a specific problem. A protected landscape area is a general term referring to a territory which is unique or very significant due to its natural, aesthetic and cultural value where the scope of qualitative or quantitative restrictions of anthropogenic activities differs.

A protected landscape area (hereinafter referred to as the CHKO) is the second highest level of environmental protection, preceded only by the status of national parks. Large areas with harmonically shaped landscape, specific relief, a significant share of natural eco-systems of forest and permanent grass vegetation, with plentiful woody plants and sometimes also with extant traces of historic settlements can be declared protected landscape areas. These areas are economically used in harmony with rules applicable to the specific protection zone with the aim to maintain and improve their natural state and to retain and create the best ecological functions of the territory. The utilization of such areas for recreational purposes is admissible if it does not damage the natural values of the protected landscape areas. A CHKO, its role and specific protection terms and conditions are declared by means of a government decree.

Nowadays, there are 25 CHKOs in the Czech Republic (the Beskydy Mountains, the Bílé Karpaty Mountains, Blaník Hill, the Blanský Les Region, the Broumov Region, the České Středohoří Highlands, the Bohemian Karst, the Český Les Mountains, the Český Ráj Region, the Jeseníky Mountains, the Jizerské Mountains, the Kokořín Region, the Krrivoklát Region, the Elbe Sandstone Rocks, the Litovelské Pomoraví Region, the Lužické Mountains, the Moravian Karst, the Orlické Mountains, the Pálava Region, the Odra River Region, the Slavkovský Les Mountains, the Šumava Mountains, the Třeboň Region, the Žd'árské Highlands, the Železné Mountains).

Ecotourism is considered an important sustainable development tool because it is "responsible travel to natural areas that conserves the environment and improves the well-being of local people" (definition of ecotourism by The International Ecotourism Society in 1990 - United Nations Environment Program, 2002). In fact, ecotourism not only brings economic benefits to local communities such as increasing local employment and income but also makes tourists "more aware of nature and more supportive of its conservation via changes in their personal behaviour, greater political support and larger financial contributions for such conservation". $[10,11]$ Thus, many countries have promoted ecotourism to national parks and protected areas. 
From the point of view of tourism, the adherence to the following bans and rules is important in protected landscape areas: no camping and making a fire outside locations approved by an environmental protection body, no arrival and stay of motor vehicles and caravans outside roads and local streets and sites approved by an environmental protection body, no biking competitions outside roads, local streets and sites approved by competent bodies.

\section{$1 \quad$ Methods of Research}

The survey took place in October and November 2019 and in March 2020. The survey was partly performed by students of tourism at the University of Economics and Business as a part of their bachelor thesis polls. The objective of the survey was to identify the extent of awareness of sustainable tourism, the positives and/or negatives the CHKO status brings to a region, and to discover the opinion on the quality of the environment and the scope of participation in its protection. Representatives of municipalities showed the lowest willingness to participate in the survey; only 6 out of 26 municipalities participated in the survey. As regards stakeholders, their participation was more extensive when 46 entities took part. The highest number of respondents came from owners of catering and accommodation facilities (41 and 37\%); in addition to the aforementioned, there were $18 \%$ of operators of tourist sights, $10 \%$ of producers of regional products and $9 \%$ of respondents were employees of information centres. Residents of the region and visitors to the region were approached personally and the principle of quota sampling was used to choose the respondents. Above all, visitors were addressed in different places and on different days of the week. As for people residing on the territory of the $\mathrm{CHKO}$, we managed to address 150 respondents. This group included all age categories and an equal share of men and women. Tourists arriving in the area were interviewed in person. They were intentionally addressed at various locations of the $\mathrm{CHKO}$ and on various days of the week. A total of 166 respondents participated in the survey.

\section{$2 \quad$ Results and Discussion}

The existence of the Moravian Karst CHKO is perceived positively by 5 out of 6 municipalities. In their opinion, tourism contributes to the economic development of the region. It creates jobs for local people. However, on the other hand, tourism adversely influences the environment and local people. There is heavy traffic in the region which deteriorates the local roads and requires more money for their maintenance. Residents might consider the high number of tourists disturbing rather than useful. Municipalities appreciate the helpful cooperation under the Association for the Development of Rural Areas in the Moravian Karst and activities of local action groups. Municipalities understand sustainable tourism as tourism with a maximum reduction of adverse features, respect to the environment and balanced development that takes the environmental protection, benefits for the society and stable economic growth into consideration without emphasizing profit maximization.

$56 \%$ of respondents operating in business know the term sustainable tourism. Businessmen usually think that sustainable tourism will be gentle to the local landscape, ensure the distribution of visitors to various places within the region and retain sources for future generations. It is tourism that is sustainable on a long-term basis (which means nondestructive) as regards the impact on the landscape, local economy, and community. Other tourist sights should be promoted to prevent the concentration of tourists in 2 or 3 places within the Moravian Karst. It should be based on local sources in harmony with nature. The services should be sufficiently attractive but at the same time, their utilization should not interfere with nature much. Not all businesses participate in the process of environmental protection. However, most of them protect the environment in a certain way, most frequently by minimizing waste, recycling it and repeatedly using various things, such as dishes. They 
also educate their employees and participate in voluntary events during which the Moravian Karst is cleaned.

As for the survey among Moravian Karst citizens, the majority of respondents (73\%) are interested in the issue of environmental protection of the Moravian Karst CHKO. Only 19\% of residents are interested in the development of tourism in the CHKO. $71 \%$ of respondents directly meet tourists and their attitude towards them is mostly positive (89\%). $80 \%$ of residents think that the existence of the Moravian Karst CHKO positively influences the development of tourism in the destination. What they see as the benefit of tourism for the region is shown in Figure 1. Significant sights in the territory are more carefully protected due to tourism, which results in a higher extent of environmental protection. Moreover, local people can improve their economic situation since tourism is a field which provides and creates new jobs where local people are employed. However, tourism has a negative impact as well. Negative features include heavy traffic and related air pollution. Tourism might also disturb the lives of local people and induce additional costs. Most citizens participate in environmental protection, mostly by minimizing and recycling waste. Residents also retain rainwater and use it to take care of their gardens.

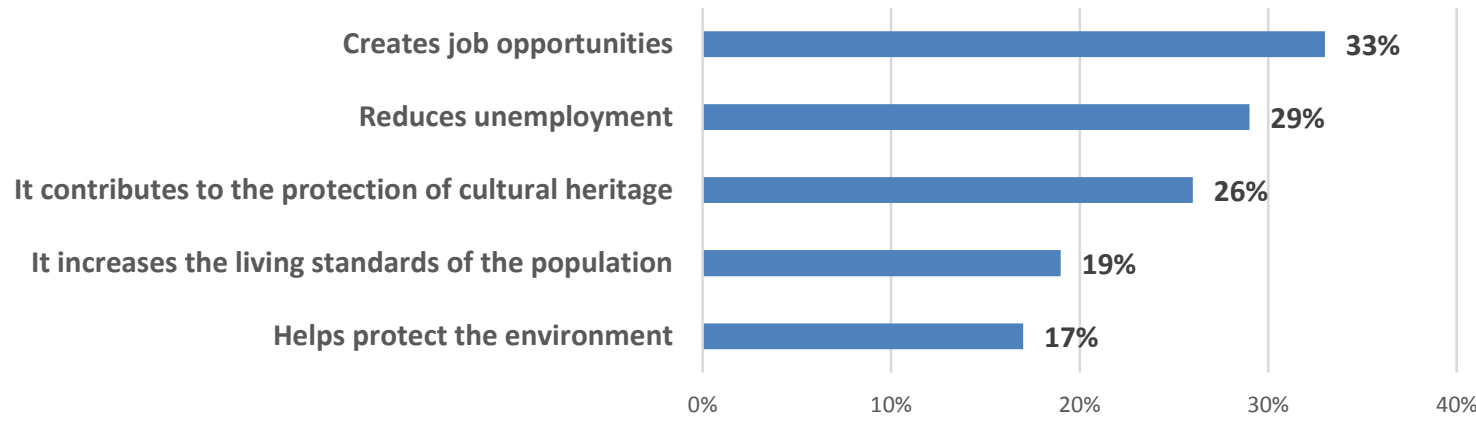

Source: Author's own survey

Fig. 1: The contribution of tourism for the CHKO Moravian Karst

Reasons to visit the Moravian Karst CHKO are listed in Figure 2 where addressed visitors were allowed to give 3 reasons at the most. Fifty per cent of respondents visited one of the caves; one-third of respondents (who usually stay for several days) expect their stay to give them an opportunity to relax. One-fifth of tourists visited cultural sights and one-quarter of them hiked or rode bikes.

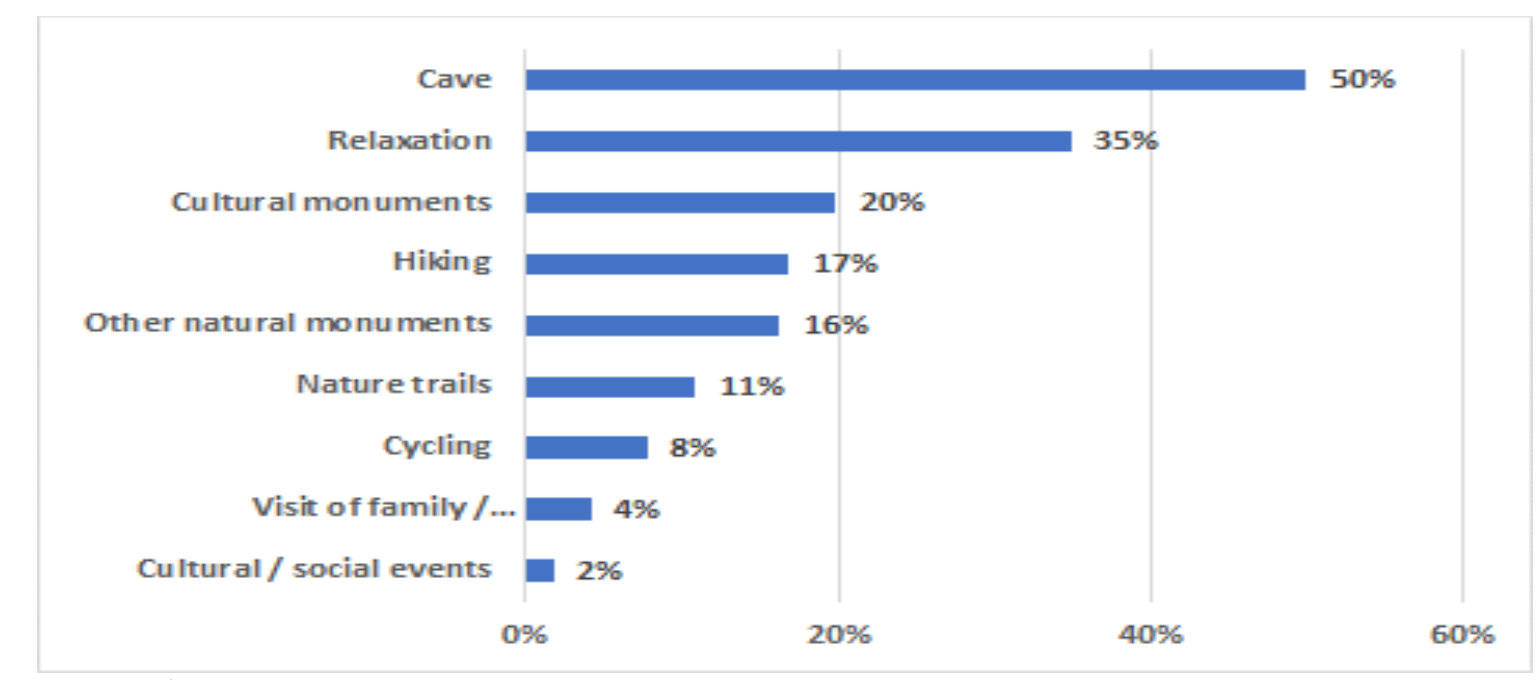

Source: Author's own survey

Fig. 2: Reasons to visit the Moravian Karst CHKO 
The sources of information before visiting the Moravian Karst included most frequently: the tourists' own experience, a recommendation from family members or friends, and internet and media (Figure 3). Every tenth tourist visited a tourist information centre.

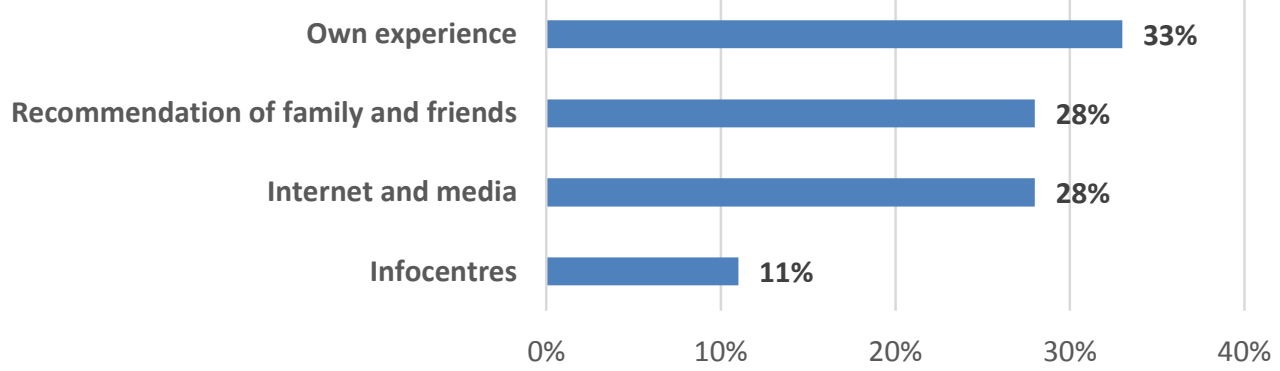

Source: Author's own survey

Fig. 3: Sources of information before the visit

Why personal experience is the most common source of information follows from Figure 4, because $57 \%$ of visitors have already visited the region. Three-quarters of visitors came by car. In the visitors' opinion, the CHKO is not overfilled with tourists. The environment is well preserved $(72 \%)$. Only one-third of visitors are familiar with the term sustainable tourism and can define it. $80 \%$ of respondents were satisfied with their visit to the CHKO. $20 \%$ of them were satisfied partly.

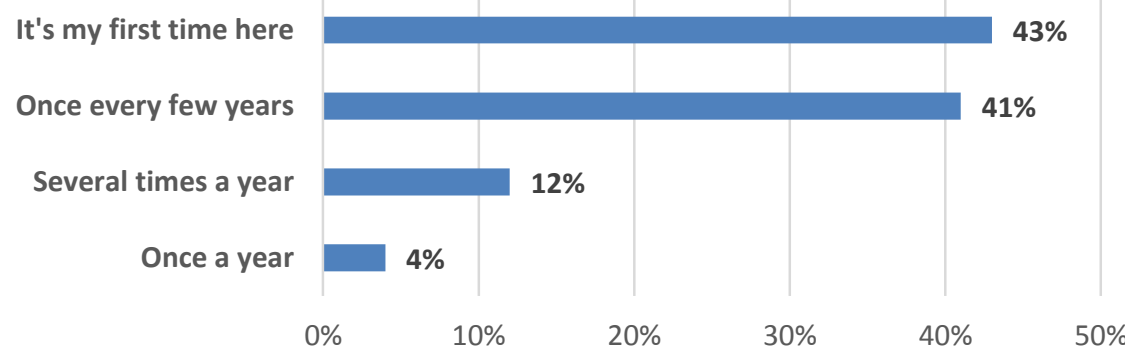

Source: Author's own survey

Fig. 4: How often do you come here?

\section{Conclusion}

The Moravian Karst is an example of a preserved landscape area that managed to combine environmental protection and tourism. Visits to caves prevail; however, visitors do not limit their activities to this type of tourist attraction. They also visit other natural as well as cultural sights.

One of the objectives of the questionnaire survey was to find out from all groups of respondents what sustainable tourism is in their understanding. Sustainable tourism is highly important in protected landscape areas. Most representatives of municipal governments knew this term. 56\% of businessmen and only $37 \%$ of local citizens and $34 \%$ of visitors were familiar with sustainable tourism. It is apparent that there is a lot of space for education and information sharing in this field.

Most municipalities think that the existence of the Moravian Karst positively influences the development of tourism. They appreciate new jobs and the inflow of finance from the regional budget. They resent the heavy traffic which results from tourism.

Stakeholders, especially owners of accommodation facilities, consider tourism very good. Most facilities are ready to accommodate handicapped visitors as well. The respondents think 
that they contribute to sustainable tourism by their effort to minimize waste and to strictly sort out refuse that can be recycled subsequently. Stakeholders would appreciate greater support of tourism by regional authorities and municipalities and better promotion of other tourist sights so that tourism is not concentrated on several most famous sights only.

Two-thirds of local citizens addressed during the survey showed interest in environmental protection. The respondents think that the CHKO as a whole is not promoted sufficiently, and attention should be focused on other places as well, not just caves. Their opinion is identical with businessmen's opinion in this aspect. They show a positive attitude to tourists and consider the creation of new job vacancies and reduction of unemployment the greatest benefit of tourism in their region. Heavy traffic is a feature that they resent.

The questionnaire survey showed that the territory attracts new visitors, but people also like to return to the region. The number of visitors is not perceived to be high and the environment in the region is considered of good quality. The survey performed among visitors showed that $86 \%$ of them spent one day in the region. Almost all of them were satisfied with the quality of services. Some of them would appreciate the improvement in the field of catering and parking.

\section{Literature}

[1] ANDERECK, K. L.; VALENTINE, K. M.; KNOPF, R. C.; VOGT, Ch. A.: Residents' Perceptions of Community Tourism Impacts. Annals of Tourism Research. 2005, Vol. 32, Issue 4, pp. 1056-1076. DOI: 10.1016/j.annals.2005.03.001

[2] DAVIS, J. S.; MORAIS, D. B.: Fraction and Enclaves: Small Towns and Socially Unsustainable Tourism Development. Journal of Travel Research. 2004, Vol. 43, Issue 1, pp. 3-10. DOI: $10.1177 / 0047287504265501$

[3] GURSOY, D.; RUTHERFORD, D. G.: Host Attitudes toward Tourism: An Improved Structural Model. Annals of Tourism Research. 2004, Vol. 31, Issue 3, pp. 495-516. DOI: $\underline{10.1016 / \text { j.annals.2003.08.008 }}$

[4] MOLDAN, B.: Podmaněná planeta. Karolinum, Prague, 2009. ISBN 978-80-246-15806.

[5] NUNKOO, R.; RAMKISSOON, H.: Small Island Urban Tourism: A Residents' Perspective. Current Issues in Tourism. 2010, Vol. 13, Issue 1, pp. 37-60. DOI: $\underline{10.1080 / 13683500802499414}$

[6] POLÁŠKOVÁ, A.: Úvod do ekologie a ochrany životního prostředí. Karolinum, Prague, 2011. ISBN 978-80-246-1927-9.

[7] RAMSEOOK-MUNHURRUN, P.; NAIDOO, P.: Residents' Attitudes toward Perceived Tourism Benefits. International Journal of Management and Marketing Research. 2011, Vol. 4, Issue 3, pp. 45-56. Available from WWW: https://www.theibfr.com/download/ijmmr/2011-ijmmr/ijmmr-v4n3-2011/IJMMRV4N3-2011-4.pdf

[8] SCAGLIONE, A.; MENDOLA, D.: Measuring the Perceived Value of Rural Tourism: A Field Survey in the Western Sicilian Agritourism Sector. Quality \& Quantity. 2017, Vol. 51, pp. 745-763. DOI: 10.1007/s11135-016-0437-8

[9] SWEENEY, J. C.; SOUTAR, G. N.: Consumer Perceived Value: The Development of a Multiple Item Scale. Journal of Retailing. 2001, Vol. 77, Issue 2, pp. 203-220. DOI: $\underline{10.1016 / \mathrm{S} 0022-4359(01) 00041-0}$ 
[10] TISDELL, C. A.: Economic Aspects of Ecotourism: Wildlife-based Tourism and Its Contribution to Nature. Sri Lankan Journal of Agricultural Economics. Vol. 5, Issue 1, pp. 83-95. DOI: $10.4038 /$ sjae.v5i0.3478

[11] TISDELL, C. A.; WILSON, C.: Economic, Educational and Conservation Benefits of Sea Turtle Based Ecotourism: A Study focused on Mon Repos. CRC for Sustainable Tourism. Gold Coast Campus: Griffith University. 2002. ISBN 1-876685-15-8. Available from

WWW: https://www.researchgate.net/publication/45937393_Economic_Educational_and_Cons ervation_Benefits_of_Sea_Turtle_Based_Ecotourism_A_Study_focused_on_Mon_Rep $\underline{\mathrm{OS}}$

[12] WOO, E.; KIM, H.; UYSAL, M. (2015). Life Satisfaction and Support for Tourism Development. Annals of Tourism Research. 2015, Vol. 50, pp. 84-97. DOI: $\underline{10.1016 / \mathrm{j} . \text { annals.2014.11.001 }}$

[13] ZÁVODNÁ, L. S.: Udržitelný cestovní ruch: principy, certifikace a měření. Univerzita Palackého v Olomouci, Olomouc, 2015. ISBN 978-80-244-4576-2.

doc. RNDr. Jiří Vaníček, CSc. 


\section{CESTOVNÍ RUCH V MORAVSKÉM KRASU}

Článek se zaměřuje na udržitelný cestovní ruch v chráněné krajinné oblasti Moravský kras. Mezi účastníky výzkumu patřily obce, zúčastněné strany $\mathrm{v}$ oblasti cestovního ruchu, obyvatelé a návštěvníci. Moravský kras (CHKO) je prríkladem zachovalé krajinné oblasti, která dokázala skloubit ochranu životního prostréedí a cestovní ruch. Převažují návštěvy jeskyní; návštěvníci však své aktivity neomezují pouze na tento typ turistické atrakce. Navštěvují také další přírodní i kulturní památky. Většina obcí si myslí, že existence CHKO Moravský kras pozitivně ovlivňuje rozvoj cestovního ruchu. Oceňují nová pracovní místa a př́liv financí z regionálního rozpočtu.

\section{TOURISMUS IM MÄHRISCHEN KARST}

Der Artikel konzentriert sich auf den nachhaltigen Tourismus im Landschaftsschutzgebiet Mährischer Karst. $\mathrm{Zu}$ den Teilnehmern der Untersuchung gehörten Gemeinden und Interessengruppen im Bereich Tourismus, Einwohner und Besucher. Der Mährische Karst (CHKO) ist ein Beispiel für ein Landschaftsschutzgebiet, dem es gelungen ist, Umweltschutz und Tourismus miteinander zu verbinden. Höhlenbesuche überwiegen; Besucher beschränken ihre Aktivitäten jedoch nicht auf diese Art von Touristenattraktion. Sie besuchen auch andere natürliche sowie kulturelle Sehenswürdigkeiten. Die meisten Gemeinden sind der Meinung, dass die Existenz des Mährischen Karstes CHKO die Entwicklung des Tourismus positiv beeinflusst. Sie schätzen neue Arbeitsplätze und den Zufluss von Finanzmitteln aus dem Regionalhaushalt.

\section{TURYSTYKA W MORAWSKIM KRASIE}

Artykuł skupia się na zrównoważonej turystyce w Parku Krajobrazowym Morawski Kras. W badaniu wzięły udział gminy, gestorzy turystyki, mieszkańcy i turyści. Morawski Kras (Park Krajobrazowy) jest przykładem zachowanego obszaru krajobrazowego, któremu udało się połączyć ochronę środowiska i turystykę. Przeważają wizyty w jaskiniach, jednak turyści nie ograniczają się do tego typu atrakcji turystycznych. Odwiedzają także inne pomniki przyrody i zabytki kultury. Większość gmin uważa, że istnienie Parku Krajobrazowego Morawski Kras pozytywnie wpływa na rozwój turystyki. Doceniają nowe miejsca pracy i napływ środków z budżetu regionalnego. 